\title{
UROLITHIASIS IN CHILDREN - A HEALTH PROBLEM OF CIVILIZATION
}

\section{KAMICA UKŁADU MOCZOWEGO U DZIECI - PROBLEM CYWILIZACYJNY}

\author{
Beata Jurkiewicz $^{1(B, C, D, E, F)}$, Joanna Katarzyna Samotyjek ${ }^{1(B, C, D, E, F)}$
}

${ }^{1}$ Clinic of Pediatric Surgery and Pediatric Urology, Centre of Postgraduate Medical Education, Warsaw, Poland

Authors' contribution

Wkład autorów:

A. Study design/planning

zaplanowanie badań

B. Data collection/entry

zebranie danych

C. Data analysis/statistics

dane - analiza i statystyki

D. Data interpretation

interpretacja danych

E. Preparation of manuscript

przygotowanie artykułu

F. Literature analysis/search

wyszukiwanie i analiza literatury

G. Funds collection

zebranie funduszy
Tables: 0

Figures: 6

References: 26

Submitted: 2016 Nov 30

Accepted: 2017 Apr 21

\section{Summary}

In the past 25 years, the incidence of urolithiasis in the paediatric population increased twofold. The reasons for the increased morbidity are not completely clear, but it is believed that many different factors impact this situation including bad eating habits, salty diets, inadequate fluid intake, obesity, hypertension, environmental pollution or uncontrolled multivitamin intake. At the same time, improving diagnostics quality and its availability contributed to an increase in the detection of urolithiasis. The paediatric population is subject to high risk of disease recurrence; therefore, it is essential to choose a method of treatment that provides a stone removal in a minimally invasive but effective way. Over $80 \%$ of bladder stones are evacuated spontaneously and do not require surgical intervention. The remaining ones need conservative or surgical treatment. A choice of the most appropriate method depends on many factors. The procedures of surgical treatment of urolithiasis in children include ESWL, URSL, RIRS, PCNL and pyelolithotomy using a laparoscopic or open technique. Urolithiasis in children is a severe interdisciplinary problem because of its more common prevalence. Its formation requires a thorough recognition, proper treatment by a nephrologist and the use of efficient, effective and minimally invasive surgical procedure.

Keywords: urolithiasis, children, ESWL, URSL

\section{Streszczenie}

W ciagu ostatnich 25 lat częstość występowania kamicy układu moczowego w populacji dziecięcej wzrosła dwukrotnie. Przyczyny zwiększonej zachorowalności nie są do końca wyjaśnione, ale uważa się, że mają na to wpływ różne czynniki: nieprawidłowe nawyki żywieniowe, dieta $\mathrm{z}$ dużą zawartością soli, niedostateczna podaż płynów, otyłość, nadciśnienie tętnicze, zanieczyszczenie środowiska oraz niekontrolowana podaż preparatów wielowitaminowych. Jednocześnie poprawa jakości i dostępności diagnostyki przyczyniły się do wzrostu wykrywalności kamicy. Populacja dziecięca narażona jest na wysokie ryzyko nawrotu choroby, dlatego zasadnicze znaczenie dla dzieci ma wybór takiej metody leczenia, która umożliwiłaby usunięcie złogów w sposób jak najmniej inwazyjny i jednoczenie skuteczny. Ponad $80 \%$ złogów wydalanych jest samoistnie i nie wymaga interwencji. Pozostałe złogi wymagają leczenia zachowawczego lub chirurgicznego. Wybór najwłaściwszej metody leczenia zależy od wielu czynników. Procedury zabiegowego leczenia kamicy u dzieci to ESWL, URSL, RIRS, PCNL oraz pielolitotomia techniką laparoskopową lub otwartą. Kamica układu moczowego u dzieci ze względu na coraz powszechniejsze występowanie jest poważnym interdyscyplinarnym problemem. Wymaga wnikliwego poznania przyczyn jej powstania, prowadzenia przez nefrologa i zastosowania skutecznego, efektywnego i jak najmniej inwazyjnego leczenia zabiegowego.

Słowa kluczowe: kamica układu moczowego, dzieci, ESWL, URSL

\section{Introduction}

In the past 25 years, the incidence of urolithiasis in the paediatric population increased two-fold [1]. The reasons for the increase if its morbidity are not completely clear, but it is believed that many different factors influenced the situation including bad eating habits, inappropriate diet, especially a salty one, products high in animal protein, inadequate fluid intake, obesity, hypertension. Environmental pollution, a fast pace of living, uncontrolled multivitamin intake and uncontrolled dietary supplement intake increase the risk of metabolic disorders leading to stone formation [2]. At the same time, improving diagnostic quality and diagnostics availability, as well as more frequent ultrasound (US) examinations in diagnosing abdominal pain, have contributed to an increase in detection of urolithiasis. [3] 


\section{Aim of the study}

The following article aims to present the current state of knowledge on urolithiasis in paediatric population.

Urolithiasis may affect patients of all ages. Scientific publications inform about a case of a 4-days-old infant with nephrolithiasis; however, the average age when this disease is diagnosed in the paediatric population is about 7-8 years [3]

The prevalence of urolithiasis in such young children usually involves metabolic disorders which are genetically predisposed. Evacuation of bladder stones from the urinary tract (spontaneous or surgical) does not finish a treatment process. The doctors should ensure that the condition in which a new crystallisation nucleus on which a stone develops does not happen again. It is not always possible to do that; therefore, there are some recurrences, mainly in children with metabolic disorders (7-50\% cases) [4].

Urolithiasis occurs familially, as about $50-60 \%$ of children have got a medical history. In retrospective studies, Naseri and Vandervoort confirm that a family history of different types of urolithiasis amount to as many as over $62.7 \%$ cases [5].

\section{Pathomechanism of stone formation}

There are numerous mechanisms of stone formation. The crystallisation of urine occurs when a crystalline nucleus appears, which causes supersaturation or deficit of crystallisation inhibitors.

The supersaturation factors usually include calcium, oxalates, uric acid, magnesium ammonium phosphates, cystine, a small urine volume or changes of urine pH [6]. As a result, small crystals develop in urine which increase and aggregate, leading to stone formation. This process may be stopped by crystallisation inhibitors, among which the most important are pyrophosphates, glycosaminoglycans, magnesium chlorides, citrates, nephrocalcin, osteopontin and Tamm-Horsfall protein. These inhibitors preclude aggregation of crystallisation nucleus and adhesion to urothelium. Also, a factor that seems relevant in inhibition of crystallisation is increased diuresis [7].

Among metabolic disorders predisposing nephrolithiasis are hypercalciuria, hyperoxaluria, hyperphosphaturia, hyperuricosuria, hypomagnesuria, cystinuria, hypocitraturia.

Hypercalciuria turns out to be the most common in children, as it is the cause of $60 \%$ of urolithiasis cases. In laboratory tests, the amount of calcium excreted in the urine exceeds $4 \mathrm{mg} / \mathrm{kg} / 24$ hours $(0,1 \mathrm{mmol} / \mathrm{kg} / 24$ hours). Three types of hypercalciuria can be distinguished: absorptive, renal and resorptive. In absorptive hypercalciuria, an increased calcium absorption takes place in the digestive tract and thereby increasing calcium concentration in blood and excreted urine. In renal hypercalciuria, the disorder is caused by a decreased calcium re-absorption in the renal tubule. If metabolic symptoms occur in a child under 10 years old, it impairs treatment response, and the prognosis is not good [1].

Another important cause of crystallisation in the urinary system are infections. Among the bacteria contributing to stone formation are Proteus spp., Klebsiella spp., Pseudomonas spp. The bacteria producing enzymes degrade urine components and change urine $\mathrm{pH}$. Proteus spp. producing urease causes the precipitation of phosphate stones, whereas Klebsiella spp. and Pseudomonas spp. produce struvite stones. Bacteria may become a crystallisation nucleus. The urinary tract infections occur in about $50 \%$ of the patients with urolithiasis, and in small children (under 5 years old) the incidence of such cases is about $62 \%$ [8].

The $\mathrm{pH}$ of urine is critical in stone formation. The acidic $\mathrm{pH}$ of urine causes a precipitation of uric acid stones and cystine stones, and the alkaline $\mathrm{pH}$ leads to the crystallisation of phosphates.

The development of genetics has contributed to the identification of mutations responsible for metabolic disorders in patients with urolithiasis. These include the following: X-linked diseases - Dent disease, Lowe syndrome and autosomal recessive diseases - Bartter syndrome type I, II, III, V, hypomagnesemia with hypercalciuria and nephrocalcinosis.

Furthermore, stone formation in the urinary tract is also caused by long-term immobilisation (causing increased calcium resorption from bone), hyperparathyroid, sarcoidosis as the cause of hypercalciuria, myeloproliferative diseases, i.e. hyperuricosuria, long-term use of loop diuretics, corticosteroids, an overdose of vitamin D and long-term parenteral nutrition of premature newborns leading to hyperoxaluria.

Stones develop in the urinary tract because of urinary reflux disorders in particular segments of the urinary system. Thus, defects and diseases causing urinary retention result in the crystallisation process. The most common abnormalities include hydronephrosis, ureterovesical stenosis, urethral stenosis and bladder disorders. In these cases, the method of choice is surgical treatment consisting in the removal of the cause of urinary reflux disorder. 
The cause of stone formation has to be determined in each child so that the primary condition is cured and any further stone formation in the urinary tract is prevented [9].

\section{Symptoms}

Urolithiasis in children is most often diagnosed during the diagnostics of abdominal pain or a routine ultrasound examination. The most common sign of urolithiasis is a pain. Typical attacks of renal colic occur in $1 / 3$ of older children, but in younger children abdominal pains are difficult to diagnose [10]. They are of different nature and non-specific enough. The symptoms include the following: nausea, vomiting, loss of appetite, dysuric symptoms, frequent urination, frequent recurrent urinary tract infections, pyuria, bacteriuria, microhematuria, whereas in infants - one can observe latericeous sediment on nappy and a small body weight gain [11].

There is also a big group of patients, i.e. $15-25 \%$, mainly younger children, in whom there are not any symptoms of nephrolithiasis. [12]

\section{Diagnostics}

If urolithiasis is suspected, diagnostics should start from a very detailed medical history with particular regard to recent diseases, medicines and/or dietary supplements, eating habits, amount of fluid intake and positive family history.

Laboratory tests include urinalysis, ionogram, uric acid, parameters of renal function, metabolites of vitamin D3, PTH (parathormone), 24-h urine collection to determine calcium concentration, calcium/creatinine ratio, cystine/creatinine ratio and oxalate/creatinine ratio.

These tests aim to determine the type of lithiasis and how the conditions leading to crystallisation nucleus can be corrected.

Another method of choice in diagnosing the condition is imaging, an ultrasound. It provides much information about the stone localisation and its size and shows any anatomical anomalies in the urinary system. It also indicates whether the stone is the cause of urinary reflux disorder or not. Radiography is not as accurate as ultrasound and exposes the patients to ionising radiation; however, it shows the majority of stones. (Fig.1)

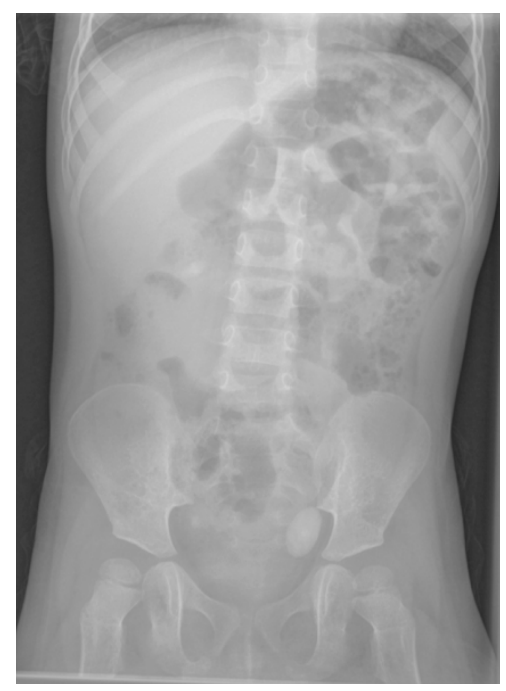

Figure 1. Large stone in the left ureter; an X-ray

To choose an appropriate method of an invasive treatment, one needs to extend diagnostic imaging and perform the following examinations: urography, computed tomography and renoscintigraphy, mainly in staghorn lithiasis.

\section{Treatment}

The paediatric population is subject to a high risk of the disease recurrence; therefore, it is vital to choose such a method of treatment that provides the stone removal in minimally invasive and efficient way. Over $80 \%$ of stones are evacuated spontaneously and do not require surgical intervention [12] (Fig.2). 


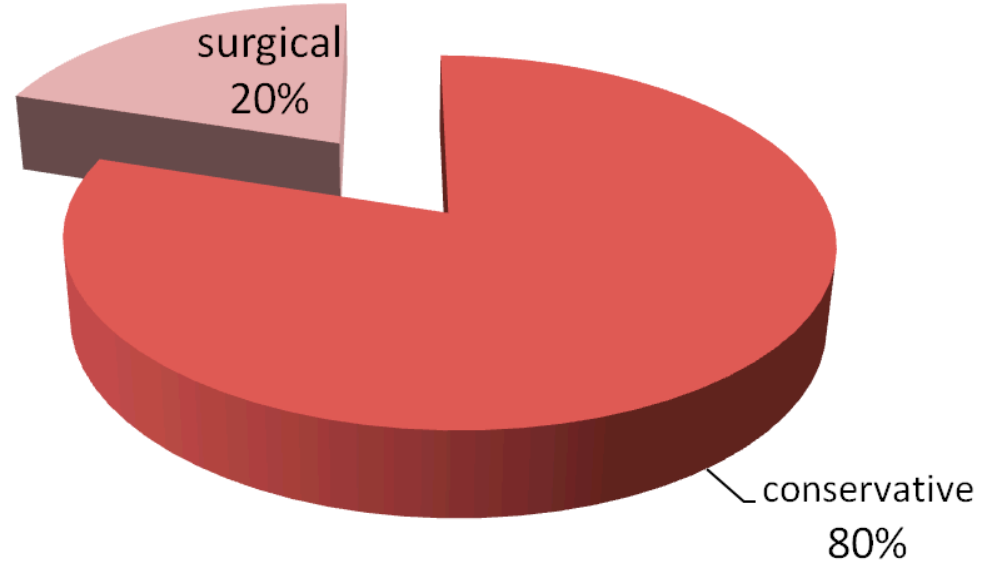

Figure 2. Methods of urolithiasis treatment

The remaining ones need conservative treatment or surgical treatment. The choice of the most appropriate method of treatment depends on many factors, i.e., the location, size and stone composition, the age of the patient, anatomical conditions, grade of urinary reflux disorder, recurrent urinary tract infections [13].

The conservative treatment of urolithiasis and recurrence prevention consist in creating such conditions which prevent the crystallisation process and an increase of crystals. It may be obtained by the $\mathrm{pH}$ of urine modification, increase in diuresis, decrease in intake or intestinal absorption of the substrate, increase in the content of crystallization inhibitors.

In all patients, regardless of urolithiasis type, a low electrolyte liquid intake during the treatment is recommended so that the specific gravity of urine would not exceed 1015 and a diuresis would be over $1 \mathrm{ml} /$ $\mathrm{kg} /$ hour. It considerably decreases the risk of crystallisation of calcium oxalate, calcium phosphate and uric acid [14].

It is also recommended to limit sodium in a diet to $100 \mathrm{mmol} /$ day and animal protein intake as well as to increase fruit and vegetable intake in a diet, which are a natural source of citrates [15].

Further, antibacterial prophylaxis is used in patients with urolithiasis. To remove stones, or cause a spontaneous stone evacuation and obtain proper urolithiasis risk indicators, one needs to take nitrofurantoin $1-2 \mathrm{mg} / \mathrm{kg}$ of body weight in a single nocturnal dose or trimethoprim in the dose of $1 \mathrm{mg} / \mathrm{kg} /$ day.

To relieve the pain, diastolic agents facilitating spontaneous stone evacuation are applied [9].

The presence of stone in the urinary system does not mean a surgical treatment. [16]. It is considered that about $60-70 \%$ of stones are evacuated spontaneously. The stones that do not cause retention of urine, of smaller diameter as $4-6 \mathrm{~mm}$, should be observed and treated only conservatively. Besides, it was observed that stone composition has a relevant influence on spontaneous evacuation. Calcium phosphate stones were spontaneously evacuated in $78 \%$ of the patients, whereas $91 \%$ of the calcium oxalate stones required surgical treatment. The cystine and struvite stones usually require a surgical procedure because of their stability and big sizes [16].

\section{Surgical treatment}

The procedures of surgical treatment of urolithiasis in children are the same as in adults. They include ESWL, URSL, RIRS, PCNL and pyelolithotomy either using a laparoscopic or an open technique.

\section{ESWL}

Extracorporeal shock wave lithotripsy (ESWL) is a non-invasive treatment that uses an acoustic pulse. The lithotripters are divided into electrohydraulic, piezoelectric and electromagnetic - depending on the mechanism of a shockwave. The shockwave is focused directly on the stone under X-ray or ultrasound control. ESWL is a method of choice in the treatment of stones with a diameter $\leq 15 \mathrm{~mm}$ located in the upper urinary tract. [17] The efficiency of the discussed method varies from $68 \%$ to $92 \%$ depending on the health centre [18]. Extracorporeal lithotripsy as monotherapy is a relatively more efficient method in the paediatric population than in adults because of stones softness, their smaller sizes, the smaller volume of patients' tissues during the shockwave transmission and amore magnificent facility in the spontaneous evacuation of crushed stones. [19] The complications after the ESWL include bleeding from the urinary system, bruising, hematoma of the renal 
parenchyma and renal colic[18]. Other complications such as worsening of the kidney function or hypertension have not been observed [20], which may mean that ESWL can be considered as a safe procedure. It is worth noting that this procedure requires a general anaesthesia at any time. Therefore, if the probability of failure is high, an alternative method of treatment should be considered that would facilitate stone evacuation even after one anaesthesia.

\section{PCNL}

Percutaneous nephrolithotomy (PCNL) is a minimally-invasive procedure which is performed in general anaesthesia and using antibiotic therapy. Using radiological or ultrasound guidance, it perforates percutaneously a renal calyx, then a nephroscope is introduced, and the stones are crushed. To defragment stones, pneumatic, ultrasonographic or laser (Ho: YAG) lithotripters may be used.

The most common complications related to this procedure are fever, urosepsis and intensive bleeding requiring a blood transfusion. However, the authors from different health centres show that a risk of blood transfusion is minimal [19]. The efficiency of PCNL as monotherapy varies from 87\% to 98.5\% [21]. To increase the effectiveness of this method, the so-called "sandwich therapy is implemented in many health centres. After the PCNL procedure, ESWL may additionally be used. This way of treatment may attain better efficiency, even $100 \%$ [22]. However, PCNL is a technique requiring extensive experience and it is a good alternative for surgical treatment.

\section{URSL}

Ureteroscopic lithotripsy (URSL) is a procedure of ureteroscopy extending up to the pyeloureteral junction. With the use of miniature semiflexible and flexible ureteroscopes, it is possible to perform ureteroscopy of the renal pelvis and secondary renal calyces and crush stones by a lithotripter (RIRS procedure) (Fig 3).

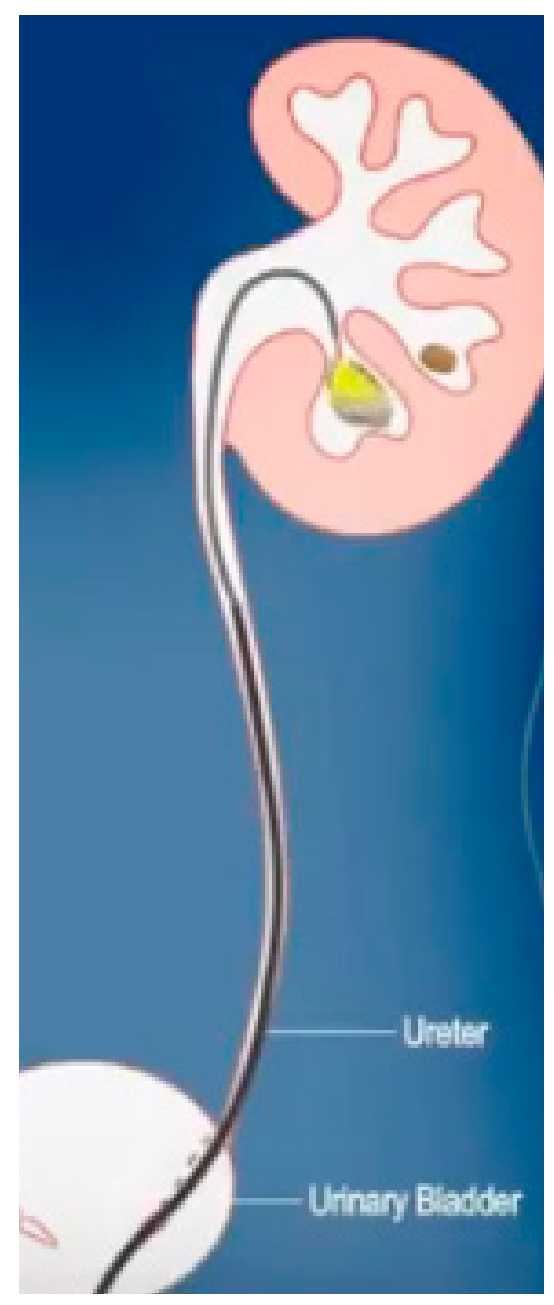

Figure 3. Retrograde intrarenal surgery (RIRS) 
Corcoran et al. received 88\% of efficiency after a single method using Ho: YAG lithotripters in a group of 47 children with stones located in the upper part of the urinary system [23]. Among the complications related to URSL, one can mention the following: ischaemia, stenosis, ureteral perforation and vesicoureteral reflux. However, the difficulty risk is inconsiderable, about $2-4 \%$ [24].

URSL is commonly used in the health centres where the authors work with the efficiency rate about $95 \%$.

From January 2013 to February 2016, 164 URSL procedures were performed in patients aged from 6 months to 17 years old, the mean age being 10.5 years. The mean duration of procedure was $13.4 \mathrm{~min}$. The smallest child weighed $6 \mathrm{~kg}$. A pneumatic probe was most often used during lithotripsy, and the crushed stones were located mainly in a distal part of the ureter (69\%) (Fig 4, 5).
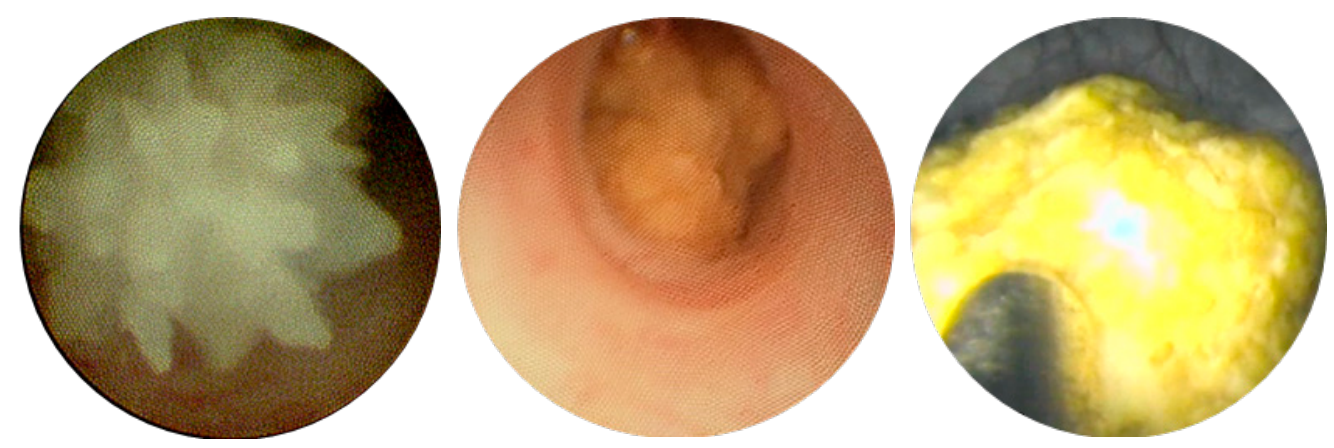

Figure 4. Stones in the ureters

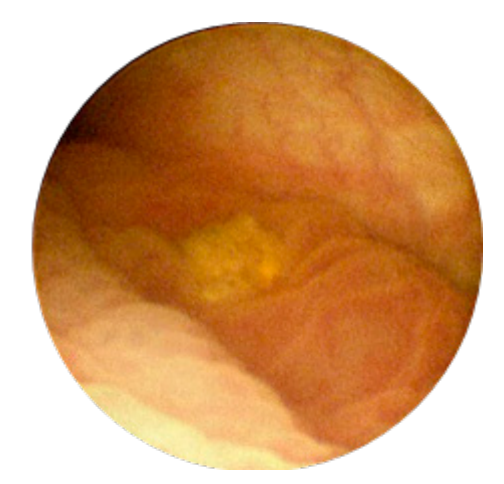

Figure 5. Stone in the ureteral orifice

In $94.7 \%$ of the patients, an outstanding result was achieved.

Pyelolithotomy is an open or laparoscopic method, which is rarely used due to the significant development of minimally invasive techniques. The primary indication for an open surgery is staghorn lithiasis including the renal pelvis and at least three groups of calyces. During a single procedure, all stones may be removed from the kidney without renal parenchymal damage. The number of pyelolithotomy cases has decreased radically [25]; however, open surgery still plays a significant role in the treatment of urolithiasis in children. About 1-5.4\% of patients with urolithiasis still require surgical procedure with appropriate medical equipment and good teams of experienced specialists in different health centres in the world [25]. Open surgery is indicated in cases of anatomical anomalies coexisting with urolithiasis, i.e., sub-pelvic stenosis, or when the use of PCNL or ESWL is difficult or impossible.

The authors have developed and described a new alternative method to a classical open surgery. By combining pyelolithotomy and endoscopy, concrements may be removed, which clears the diseased kidney without causing parenchymal damage during each procedure. The method is safe for children, does not require a blood transfusion, and helps maintain the kidney function. This procedure is dedicated to complicated cases of staghorn urolithiasis [26] (Fig 6). 

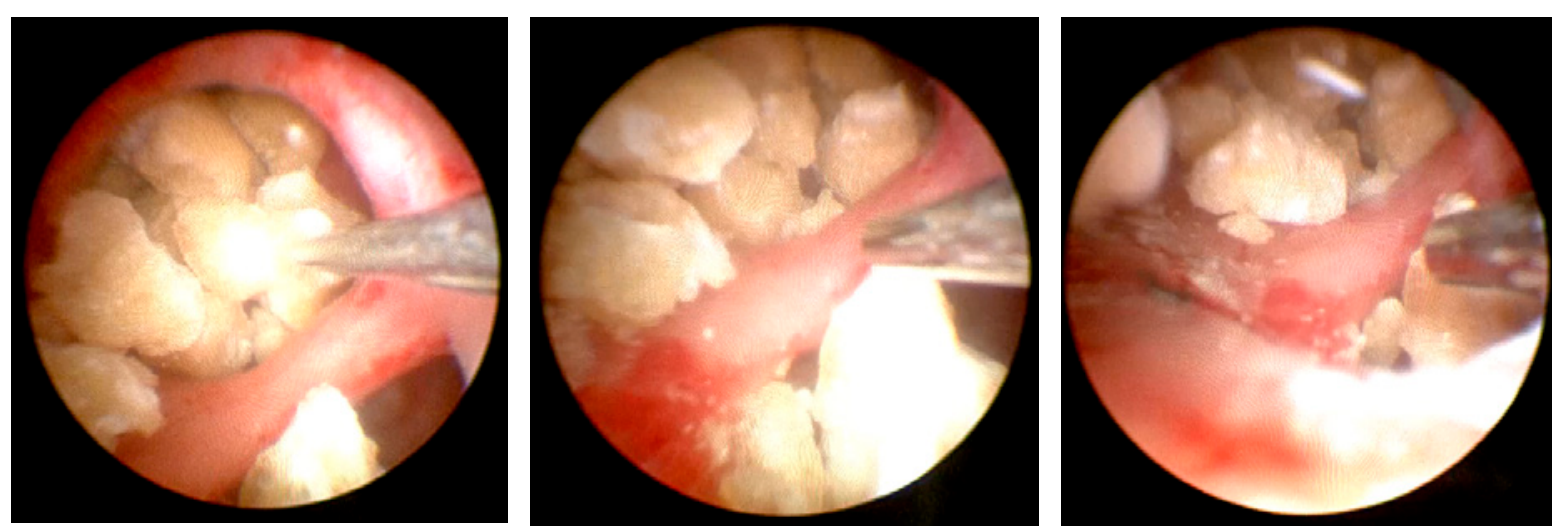

Figure 6. Stones in the pelvis and calyces kidney

\section{Conclusion}

Urolithiasis in children is a severe interdisciplinary problem because of a more common prevalence. It requires a thorough recognition of how it is formed, a proper treatment by a nephrologist and the use of efficient, effective and minimally invasive surgical procedures.

\section{References:}

1. Xiao B, Zhang X, Hu WG, Chen S, Li YH, Tang YZ, et al. Mini-percutaneous Nephrolithotomy Under Total Ultrasonography in Patients Aged Less Than 3 Years: A Single-center Initial Experience from China. Chin Med J (Engl). 2015 Jun 20; 128(12): 1596-1600

2. Goldfarb DS. Increasing prevalence of kidney stones in the United States. Kidney Int. 2003; 63: 1951-1952.

3. Amancio L, Fedrizzi M, Bresolin N, Penido M. Pediatric urolithiasis: experience at a tertiary care pediatric hospital. J Bras Nefrol. 2016; 38(1): 90-98.

4. Spivacow FR, Negri AL, del Valle EE, Calviño I, Fradinger E, Zanchetta JR. Metabolic risk factors in children with kidney stone disease. Pediatr Nephrol 2008; 23: 1129-33.

5. VanDervoort K, Wiesen J, Frank R, Vento S, Crosby V, Chandra M, et al. Urolithiasis in pediatric patients: a single center study of incidence, clinical presentation and outcome. J Urol 2007; 177: 2300-5.

6. Acar B, Inci Arikan F, Emeksiz S, Dallar Y. Risk factors for nephrolithiasis in children. World J Urol. 2008; 26: 627-630.

7. Gower LB, Amos FF, Khan SR: Mineralogical signatures of stone formation mechanisms. Urol Res. 2010; 38: 281-292.

8. Gajengi A, Wagaskar V, Tanwar H, Mhaske S, Patwardhan S. Metabolic Evaluation in Paediatric Urolithiasis: A 4-Year Open Prospective Study. Journal of Clinical and Diagnostic Research. 2016 Feb, 10(2): PC04-PC064 4.

9. Kamińska A, Bieroza I. Kamica układu moczowego u dzieci. Nowa Pediatria. 2011; 2: $42-48$ (in Polish).

10. Penido M, Tavares M. Pediatric primary urolithiasis: Symptoms, medical management and prevention strategies. World J Nephrol. 2015 September 6; 4(4): 444-454.

11. Alon U, Warady BA, Hellerstein S. Hypercalciuria in the frequency-dysuria syndrome in childhood. J Pediatr. 1990; 116: 103-105.

12. Sofer M, Binyamini J, Ekstein PM, Bar-Yosef Y, Chen J, Matzkin H, et al. Holmium laser ureteroscopic treatment of various pathologic features in pediatrics. Urology 2007, 69: 566-9.

13. Smaldone MC, Bishoy AG, Ost MC, The evolution of endourologic management of pediatric stone disease. Indian J Urol. 2009, 25(3): 302-311.

14. Lande MB, Varade W, Erkan E, Niederbracht Y, Schwartz GJ. Role of urinary supersaturation in the evaluation of children with urolithiasis. Pediatr Nephrol. 2009; 20: 491-494.

15. Alon US. Medical treatment of pediatric urolithiasis. Pediatr Nephrol. 2009; 24: 2129-2135.

16. Jun E, Metcalfe P, Mandhane P, Alexander R. Patient and stone characteristics associated with surgical intervention in pediatrics. Canadian Journal of Kidney Health and Disease. 2015; 2: 22.

17. Ather $\mathrm{MH}$, Noor MA. Does size and site matter for renal stones up to $30-\mathrm{mm}$ in size in children treated by extracorporeal lithotripsy? Urology. 2003; 61: 212-25. 
18. Straub M, Gschwend J, Zorn C. Pediatric urolithiasis: the current surgical management. Pediatr Nephrol. 2010; 25: 1239-1244.

19. Desai MR, Kukreja RA, Patel SH, Bapat SD. Percutaneous nephrolithotomy for complex pediatric renal calculus disease. J Endourol. 2004; 18: 23-27.

20. Brinkmann OA, Griehl A, Kuwertz-Bröking E, Bulla M, Hertle L. Extracorporeal shock wave lithotripsy in children. Efficacy, complications and long-term follow-up. Eur Urol 2001; 39: 591-597.

21. Zeren S, Satar N, Bayazit Y, Bayazit AK, Payasil K, Ozkeceli R. Percutaneous nephrolithotomy in management of pediatric renal calculi. J Endourol. 2002; 16: 75-8.

22. Mahmud M, Zaidi Z. Percutaneous nephrolithotomy in children before school age: Experience of Pakistani centre. BJU Int. 2004; 94: 1352-4.

23. Corcoran AT, Smaldone MC, Mally D, Ost MC, Bellinger MF. Flexible ureteroscopy for proximal stones in pediatric patients: how complete access simplifies the surgical approach. J Endourol. 2007; 21: A84.

24. Smaldone MC, Cannon GM Jr, Wu HY, Bassett J, Polsky EG, Bellinger MF, et al. Is ureteroscopy first line treatment for pediatric stone disease? J Urol. 2007; 178: 2128.

25. Paik ML, Resnick MI. Is there a role for open stone surgery? Urol Clin North Am 2000; 27: 323-331.

26. Jurkiewicz B, Ząbkowski T, Samotyjek J, Jung A. Combined Use of Pyelolithotomy and Endoscopy: An Alternative Surgical Treatment for Staghorn Urolithiasis in Children. Endourology And Stone Diseases. 2016; 13(2): 2599-2604. 